\title{
SISTEM KEAMANAN PINTU LABORATORIUM BERBASIS SENSOR FINGERPRINT DAN MAGNETIC LOCK
}

\author{
Ardhi Wicaksono Santoso ${ }^{1, *}$, Anindita Suryarasmi ${ }^{2}$, Aditya Alvian Nugroho ${ }^{3}$ \\ ${ }^{1,2,3}$ Departemen Teknik Elektro dan Informatika, Sekolah Vokasi, \\ Universitas Gadjah Mada, Yogyakarta, Indonesia \\ Email: 1'ardhi.wicaksono@ymail.com, ${ }^{2}$ anindita@ugm.ac.id, ${ }^{3}$ adhitya.alvian17@gmail.com
}

\begin{abstract}
Abstrak
Abstrak-- Sistem pintu keamanan di laboratorium biasanya menggunakan kunci konvensional. Departemen Teknik Listrik dan Informatika, Perguruan Tinggi Kejuruan, Universitas Gadjah Mada memiliki 24 laboratorium dan puluhan ruang kelas. Semakin tinggi jumlah laboratorium dan ruang kelas, semakin banyak kunci yang dibutuhkan. Kendala yang dihadapi oleh asisten laboratorium adalah sulitnya menemukan kunci dan kehilangan kunci.Salah satu cara mengatasi masalah di atas membuat sistem penguncian pintu otomatis menggunakan sensor sidik jari. Sistem ini bertujuan untuk meningkatkan keamanan dan memfasilitasi akses untuk mengunci ruangan. Sistem ini dibuat menggunakan mikrokontroler sebagai prosesor dan sensor sidik jari. Identitas pengakses laboratorium disimpan dalam memori untuk membuka kunci pintu. Di pintu masuk, pintu kunci magnetik dipasang, yang terhubung ke sistem mikrokontroler. Sistem dapat berjalan seperti yang dimaksudkan dan dapat mendeteksi sidik jari yang tersimpan dalam memori. Sistem dapat mengidentifikasi sidik jari pengguna yang disimpan dalam memori dengan persentase keberhasilan $95 \%$ dari total 40 percobaan membuka kunci.
\end{abstract}

Kata Kunci: Sidik Jari, Kunci Magnetik, Mikrokontroller, Sistem Kunci Pintu, Keamanan

\begin{abstract}
Abstract-- The security door system in the laboratory uses conventional locks. The Department of Electrical and Information Engineering, Vocational College, Universitas Gadjah Mada has 24 laboratories and dozens of classrooms. The higher the number of laboratories and classrooms, the more keys are needed. Obstacles that are problematic by laboratory assistants are difficult to find keys and lose keys. One way to overcome the above problem is to create an automatic door locking system using a fingerprint sensor. This system encourages security and facilitates access to activate the room. This system is made using a microcontroller as a processor and fingerprint sensor. The identity of the laboratory access is opened to unlock the door. At the entrance, a magnetic door lock is installed, which is connected to the microcontroller system. The system can run as successful and can be moved with a finger stored in memory. 95\% of the total 40 trials were unlocked.
\end{abstract}

Keywords: Fingerprint, Lock Door Systems, Magnetic Lock, Microcontroller, Security

\section{PENDAHULUAN}

Perkembangan ilmu pengetahuan dan teknologi yang semakin meningkat terutama dibidang elektronika ditandai dengan pesatnya kemajuan yang terjadi dengan diciptakannya peralatan elektronika yang semakin canggih. Banyak keuntungan yang diperoleh dari perkembangan elektronika tersebut, diantaranya adalah semakin mudahnya manusia dalam menyelesaikan suatu masalah atau melakukan sesuatu sehingga waktu, tenaga, dan biaya dapat digunakan dengan lebih hemat namun efektif. Aktivitas yang bersifat rutin sekarang banyak digantikan oleh peralatanperalatan yang dirancang secara otomatis, yang dapat bekerja menggantikan tenaga manusia.

Salah satu penerapan teknologi adalah 
pengembangan aplikasi rumah/ruang pintar (smart home/room) yang dapat memberikan kenyamanan, keamanan dan efesien bagi pengguna. Penambahan teknologi identifikasi dan pelacakan, sensor-sensor, actuator, dan protokol komunikasi dapat menghasilkan sebuah sistem smartroom/smarthome (Atzori, dkk., 2010). Rumah/ruang pintar memiliki sistem otomatis untuk mengendalikan peralatan multimedia untuk memantau dan mengaktifkan sistem keamanan. Rumah/ruang pintar tampak "cerdas" karena adanya sistem komputer yang memonitoring banyak aspek pada kegiatan sehari-hari di rumah/ruangan (Bregman, 2010). Rumah pintar yang diintegrasikan dengan Programmable Logic Controller (PLC) dapat memberi kemudahan dalam mengendalikan alat-alat elektronik, peralatan listrik, dan lampu (Triawati dan Firman, 2010). Teknologi smartphone juga dapat digunakan, dengan cara diintegrasikan dengan sistem tertanam dapat menghasilkan inovasi dalam pengendalian peralatan di dalam rumah secara otomatis. Teknologi ini memungkinkan untuk menghasilkan teknologi pengamanan serta otomasi pada proses membuka dan menutup pintu (Muhira Dzar Faraby, dkk., 2016).

Rumah pintar merupakan tempat tinggal atau hunian yang memanfaatkan jaringan komunikasi yang dihubungkan dengan peralatan listrik untuk mengendalikan dan memonitor secara jarak jauh. Penggunaan teknologi berbasis IP (Internet Protocol) pada rumah pintar memungkinkan pengguna memantau dan mengelola peralatan rumah tangga (lampu). Salah satunya adalah menggunakan perangkat seluler yang terhubung ke Internet Wireless untuk mengakses lingkungan rumah (Kusriyanto dan Putra, 2016).

Rumah pada umumnya menggunakan kunci manual pada pintu sehingga dapat dikatakan tingkat keamanan rumah relatif rendah. Sistem kemanan pintu menggunakan smartcard berbasis RFID (Radio Frequency Identification), diharapkan dapat menjadi alternatif untuk aplikasi kunci elektris pada pintu/ruangan (Hanifah, dkk., 2010). Selain RFID, teknologi akses ke dalam sebuah ruangan bisa menggunakan sidik jari. Dengan menggunakan metode ini akan mengatasi seringnya kehilangan kunci dan kesulitan untuk menemukan kunci yang digunakan untuk membuka ruangan, dikarenakan semakin banyak ruang maka semakin banyak kunci yang disediakan (Saputra, dkk., 2014).

Fingerprint atau sensor sidik jari adalah salah satu perkembangan teknologi yang memiliki keamanan yang cukup tinggi dimana sidik jari merupakan garis yang terdapat pada guratan garis jari tangan yang sering digunakan untuk keperluan pengenalan identitas seseorang yang bisa diakses oleh orang yang sidik jarinya sudah di-input ke dalam Fingerprint (Iskandar, dkk., 2017).

Sensor Fingerprint adalah sebuah perangkat elektronik yang digunakan untuk menangkap gambar digital dari pola sidik jari, gambar tersebut disebut pemindaian hidup. Pemindaian hidup adalah pemrosesan digital untuk membuat sebuah template biometrik yang disimpan dan digunakan untuk pencocokan Sensor Fingerprint ini memiliki kemampuan pembacaan sidik jari dengan tingkat sensitivitas yang tinggi baik dalam keadaan basah maupun kering. Selain itu alat ini memiliki kecepatan tinggi saat melakukan sistem pemindaian, pencarian dan pembandingan pola sidik jari (Saiful, 2016).

Sidik jari merupakan identitas pribadi yang tidak mungkin ada yang menyamainya. Sifatsifat atau karakteristik yang dimiliki oleh sidik jari adalah perennial nature yaitu guratanguratan pada sidik jari yang melekat pada manusia seumur hidup, immutability yang berarti bahwa sidik jari seseorang tak akan pernah berubah kecuali sebuah kondisi yaitu terjadi kecelakaan yang serius sehingga mengubah pola sidik jari yang ada dan individuality yang berarti keunikan sidik jari merupakan originalitas pemiliknya yang tak mungkin sama dengan siapapun di muka bumi ini sekali pun pada seorang yang kembar identik (Sinaga dan Tamba, 2013). Pada sistem keamanan yang menggunakan Fingerprint, memiliki tingkat kesulitan lebih rendah jika dibandingkan dengan tingkat kesulitan apabila menggunakan password (Hugh, 2011).

Departemen Teknik Elektro dan Informatika (TEDI), Sekolah Vokasi, UGM adalah salah satu departemen yang mengelola banyak program studi. Departemen ini memiliki sarana dan prasarana kelas serta laboratorium yang banyak untuk menjalankan kegiatan belajar mengajar. Jumlah layanan laboratotium di departemen ini lebih dari 20 layanan yang terbagi di 2 lokasi. Sehingga perlu pengelolaan dan pengawasan yang baik untuk menjaga kelancaran kegiatan belajar mengajar.

Berdasarkan latar belakang tersebut, pada 
naskah ini akan dipaparkan perancangan sistem keamanan pintu berbasis sensor Fingerprint yang diimplementasikan di layanan laboratorium di departemen TEDI, Sekolah Vokasi, UGM. Teknologi ini diharapkan dapat memudahkann pengguna laboratorium dalam membuka pintu ruangan tanpa harus mencari kunci, dan keamanan ruanganpun lebih terjamin karena hanya yang sidik jarinya terdaftar saja.

\section{METODE}

Pada bagian ini akan dipaparkan perancangan sistem pengaman pintu berbasis sensor Fingerprint. Sistem terdiri dari empat bagian utama, yaitu bagian masukan (input), pemroses, keluaran (output) dan bagian catu daya. Secara keseluruhan bagian sistem ditunjukkan pada Gambar 1.

Pada bagian input terdapat sensor Fingerprint FPM10A yang digunakan sebagai pendeteksi sidik jari. Pendeteksian sidik jari dilakukan secara elektronik kemudian hasil deteksi disimpan dalam bentuk format digital. Data digital dalam bentuk pola fitur jari tersebut kemudian disimpan dalam memori penyimpanan dalam bentuk ID sidik jari. Data ID sidik jari inilah yang kemudian diambil melalui komunikasi serial oleh pemroses sebagai input sistem.

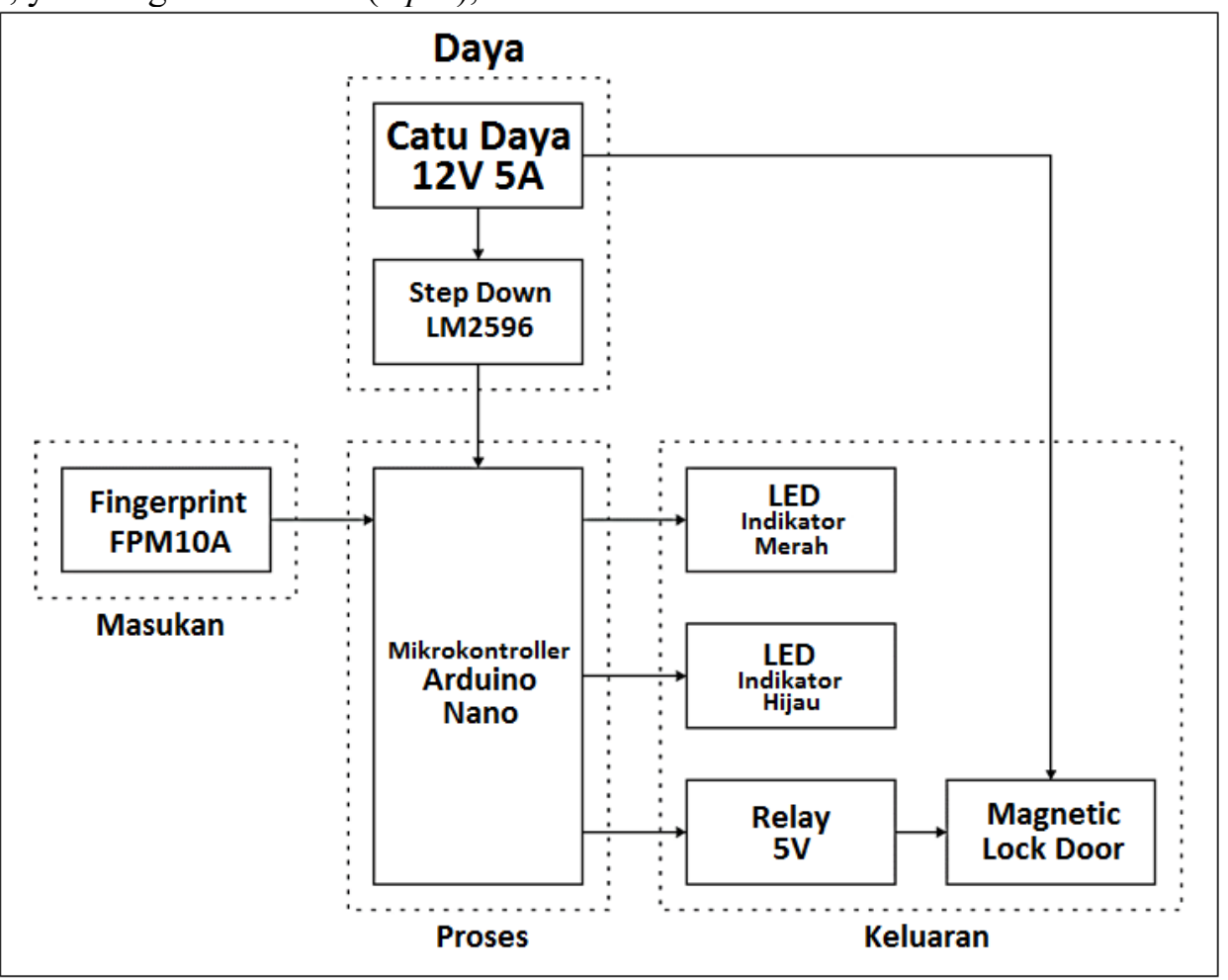

Gambar 1. Bagian Sistem Pengaman Pintu Berbasis Sensor Fingerprint

Pada sistem yang dirancang pemrosesan dilakukan menggunakan mikrokontroler Arduino Nano. Mikrokontroler ini menggunakan IC ATmega 328 yang memiliki kapasitas flash memory sebesar 32 Mbyte dengan kecepatan clock $16 \mathrm{MHz}$ dengan spesifikasi lainnya ditunjukkan pada Tabel 1.

Pada sistem yang dirancang, digunakan pin digital yang berfungsi sebagai input dan output. Pada Gambar 2 ditunjukkan skema pinout dari Arduino Nano secara keseluruhan.

Pada sistem pin digital yang digunakan 7 pin digital, 4 pin sebagai input dan 3 pin sebagai output sistem. Pada Tabel 2 ditunjukkan penggunaan pin digital pada Arduino Nano untuk perancangan sistem.
Tabel 1. Spesifikasi Arduino Nano (Arduino Nano User Manual, 2008)

\begin{tabular}{|c|c|c|}
\hline No & Unit & Spesifikasi \\
\hline 1 & Tegangan kerja & 5 Volt \\
\hline 2 & Tegangan masukan & Optimal 7-12 Volt \\
\hline 3 & Minimum: 6 V & Maksimum: 20 V \\
\hline 4 & Digital pin I/O & Pin digital D0-D13 \\
\hline 5 & Analog pin & 8 pin analog A0-A7 \\
\hline 6 & Arus maksimum & $40 \mathrm{~mA}$ \\
\hline 7 & Flash Memory & $32 \mathrm{Mbyte}$ \\
\hline 8 & SRAM & 1kybte \\
\hline 9 & EEPROM & 1 kbyte (Atmega328) \\
\hline 10 & Kecepatan clock & $16 \mathrm{MHz}$ \\
\hline 11 & Ukuran board, berat & $4,5 \mathrm{x} 18 \mathrm{~mm}$; 5gram \\
\hline
\end{tabular}




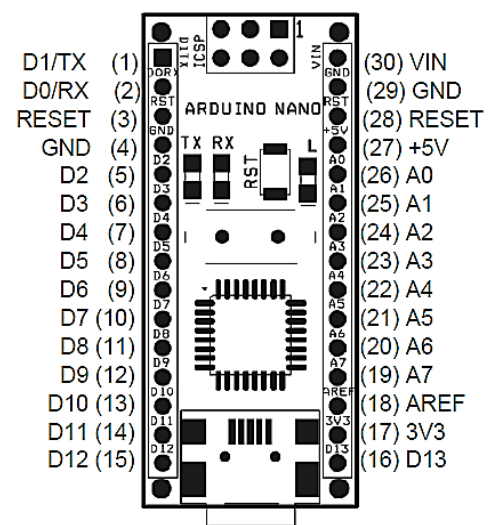

Gambar 2. Skema Pinout Arduino Uno (Arduino Nano User Manual, 2008)

Tabel 2. Penggunaan Pin Digital pada Arduino Nano

\begin{tabular}{|c|c|c|}
\hline No & Pin & Fungsi \\
\hline 1 & D2 & Pin TX Sensor Fingerprint \\
\hline 2 & D3 & Pin RX Sensor Fingerprint \\
\hline 3 & D4 & Output Magnetic Lock \\
\hline 4 & D5 & Input Limit switch (Autolock) \\
\hline 5 & D6 & Input Switch (Buka Manual) \\
\hline 6 & D7, D8 & Indikator LED Output \\
\hline \multicolumn{3}{|c|}{ Pin D2 dan D3 merupakan pin yang } \\
\hline
\end{tabular}
dihubungkan pada sensor Fingerprint. Pin D4 digunakan mmengubah kondisi relay yang terhubung dengan Magnetic Lock untuk mengaktifkan magnet (kunci aktif) dan menonaktifkan magnet (kunci terbuka). Pin D5 digunakan untuk menerima input kondisi limit switch sebagai pengunci otomatis ketika pintu tertutup. Pin D6 digunakan untuk menerima input dari tombol switch untuk membuka pintu secara manual dari dalam Lab. Sedangkan pin D7 dan D8, masing-masing untuk mengaktifkan indikator LED warna merah (kunci aktif) dan LED warna hijau (kunci terbuka).

Perangkat keras yang disusun kemudian diantarmuka dengan software melalui pemrograman di Arduino Nano. Pemrograman pada Arduino Nano menggunakan library sebagai antarmuka sensor Fingerprint, alur program pada Arduino Nano ditunjukkan pada Gambar 3.

Pertama kali sistem akan menginisialisasi variabel yang digunakan termasuk Library Fingerprint yang digunakan sebagai antarmuka sensor Fingerprint dengan mikrokontroler Arduino Nano. Inisialisasi membuat kondisi LED merah menyala dan Relay aktif yang menyebabkan Magnetic Lock bekerja (terkunci) dan sistem berada pada posisi Idle.

Saat posisi idle sistem akan menunggu input. Input dapat berasal dari tombol manual untuk membuka pintu yang terletak di dalam Lab, ataupun input yang berasal dari data sidik jari yang dideteksi oleh sensor Fingerprint yang berada di luar Lab.

Saat ada input dari tombol manual maka Arduino Nano akan mengirimkan sinyal ke relay yang menonaktifkan Magnetic Lock (terbuka). Setelah Magnetic Lock terbuka, maka sistem kembali idle, sampai pintu tertutup (limit switch terpicu).

Saat tombol manual tidak ditekan, maka sistem akan Idle dan menunggu ada input. Saat ada input dari sensor Fingerprint maka sidik jari yang terdeteksi akan dibaca apakah ID sidik jari dikenali (terdaftar) atau tidak. Apabila sidik jari dikenali, maka Arduino Nano akan mengirimkan sinyal ke relay yang akan menonaktifkan Magnetic Lock (terbuka). Magnetic Lock akan otomatis terkunci, apabila pintu tertutup (limit switch terpicu).

Dari perancangan sistem yang dilakukan, kemudian dilakukan implementasi dan pengujian sistem yang dijelaskan pada bagian Hasil dan Pembahasan.

\section{HASIL DAN PEMBAHASAN}

Pada bagian ini akan dipaparkan implementasi sistem dan hasil pengujian sistem yang dirancang. Hal ini bertujuan untuk mengetahui unjuk kerja dari sistem yang dirancang. Sistem yang dirancang, diimplementasikan di ruang Laboratorium Instrumentasi (S2.01) Gedung Herman Yohanes, Sekip III, Sekolah Vokasi, UGM.

\section{Implementasi Sistem}

Sistem diimplementasikan pada akses pintu masuk / keluar laboratorium instrumentasi yang berada di dalam ruangan S2.01. Pintu yang terpasang di ruangan merupakan jenis pintu geser. Pada Gambar 4 ditunjukkan implementasi sistem di sisi luar lab yang terdiri dari sensor Fingerprint yang dilengkapi dengan indikator LED merah penanda pintu terkunci dan LED hijau penanda pintu tidak terkunci. Sedangkan pada Gambar 5 ditunjukkan implementasi sistem di sisi dalam lab yang terdiri dari tombol pembuka kunci secara manual dan juga LED indikator warna merah dan hijau sebagai penanda pintu terkunci atau tidak terkunci.

Pada Gambar 4, posisi sensor fingerprint diletakkan di sebelah kiri (bagian dilingkari) sisi luar pintu Lab, hal ini bertujuan untuk membatasi akses masuk ke Lab. Sedangkan pada Gambar 5 ditunjukkan sisi dalam pintu Lab dan terdapat sebuah tombol (bagian dilingkari) untuk membuka kunci pintu untuk 
akses keluar dari dalam Lab.

Pada sisi pintu di dalam Lab, pintu akan secara otomatis terkunci apabila pintu tertutup. Implementasi dari pengaman pintu dan pengunci pintu ditunjukkan pada Gambar 6.

Sistem pengaman pintu dipasang magnetic lock (segi empat) yang dihubungkan ke dalam sistem. Sistem kunci otomatis dibuat dengan menambahkan limit switch (lingkaran) atau saklar yang bekerja ketika pintu tertutup sempurna. Tombol buka kunci manual ditambahkan untuk akses keluar dari Lab.

\section{Pengujian Sistem}

Tahap selanjutnya adalah melakukan pengujian terhadap sistem yang diimplementasi. Pengujian dilakukan dengan melakukan percobaan membuka kunci sebanyak 20 kali. Percobaan dilakukan dengan mencoba mevariasikan posisi jari di sensor Fingerprint untuk setiap tangan. Sehingga dilakukan 40 kali percobaan membuka kunci dengan input sensor Fingerprint dari luar Lab seperti ditunjukkan pada Gambar 7. Selanjutnya dilakukan juga 20 kali percobaan membuka kunci menggunakan tombol manual dari dalam Lab seperti ditunjukkan pada Gambar 8 yang bertujuan menguji kinerja sistem.
Pada Tabel 3 ditunjukkan pengujian sistem kunci pintu dengan input sidik jari menggunakan ibu jari tangan kanan dan pada Tabel 4 merupakan pengujian menggunakan ibu jari tangan kiri.

Berdasarkan data pada Tabel 3 dan 4 terdapat kegagalan dalam mendeteksi sidik jari. Berdasarkan dokumentasi yang dilakukan, Pada Gambar 9 dan 10 ditunjukkan kegagalan membuka kunci dan berdasarkan penempatan jari pada sensor Fingerprint untuk jari tangan kanan dan tangan kiri.

Berdasarkan Gambar 9 dan 10 dapat diketahui bahwa tidak sempurnanya posisi jari pada sensor dapat mempengaruhi pembacaan sidik jari.

Pengujian selanjutnya adalah menguji tombol kunci manual. Pengujian dilakukan sebanyak 20 kali percobaan membuka kunci. Pada Tabel 5 ditunjukkan hasil percobaan membuka kunci manual.

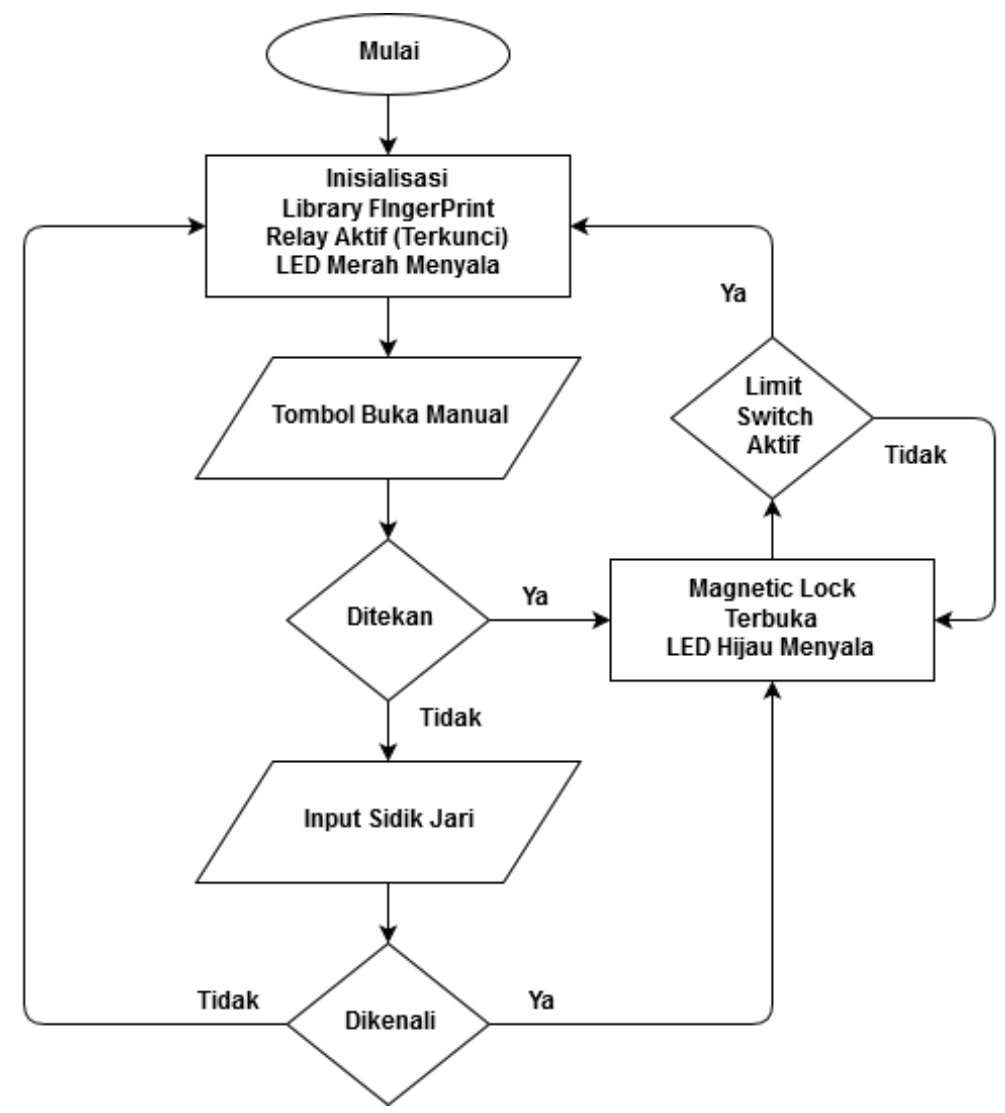

Gambar 3. Flowchart Pemrograman Arduino Nano 

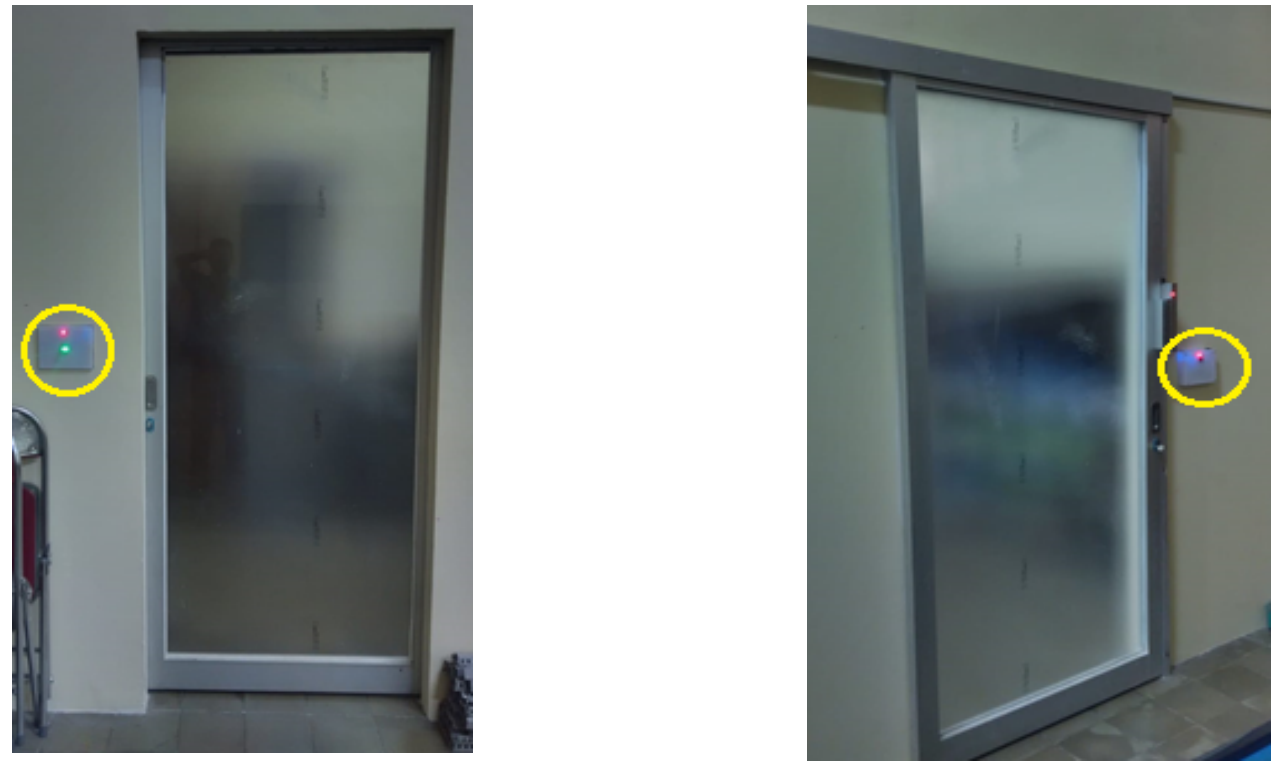

Gambar 4. Implementasi di Sisi Luar Lab

Gambar 5. Implementasi di Sisi Dalam Lab

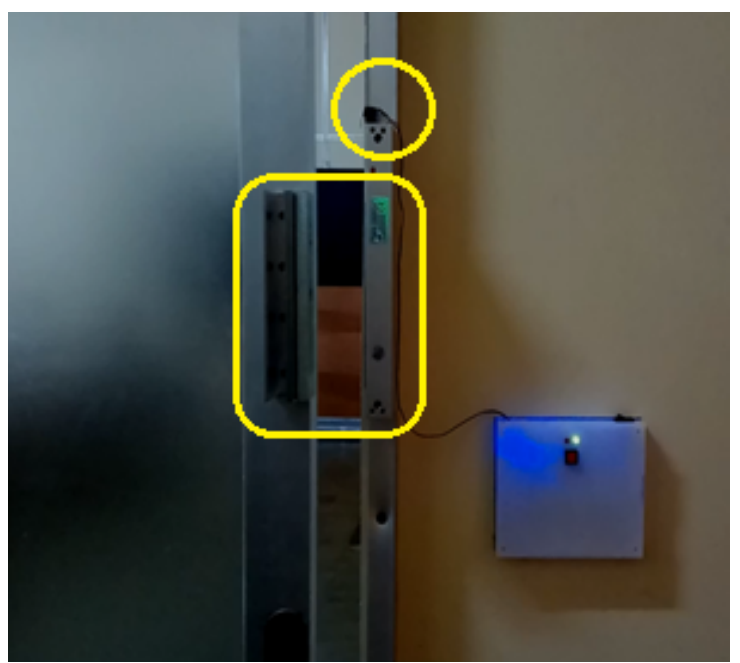

Gambar 6. Implementasi saklar manual dan kunci otomatis 

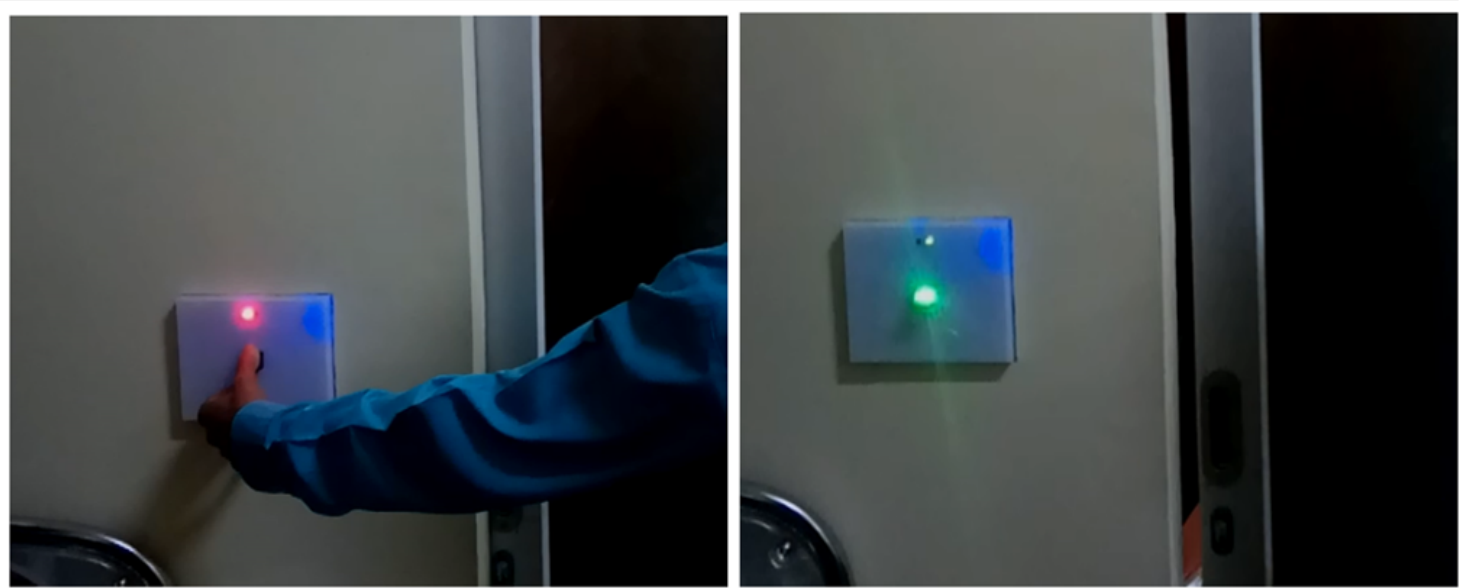

Gambar 7. Pengujian Kunci dengan Input Sidik Jari
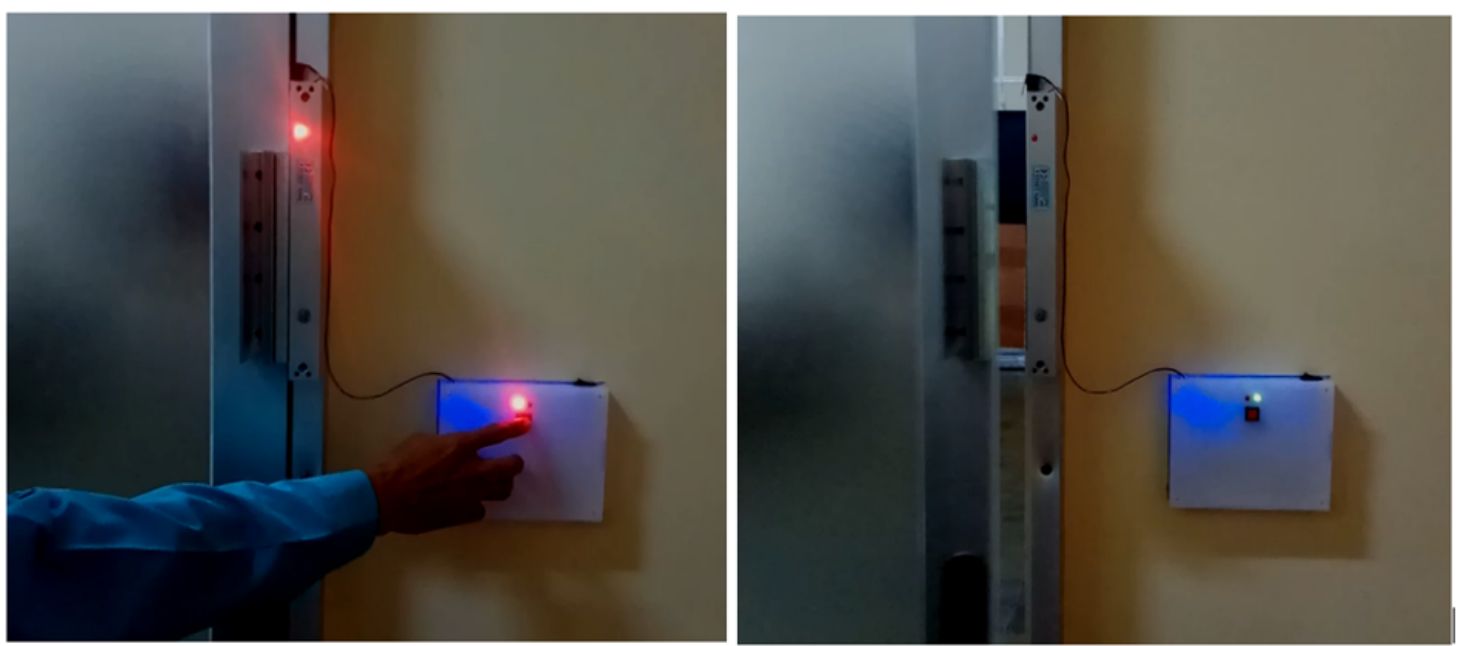

Gambar 8. Pengujian Kunci Manual

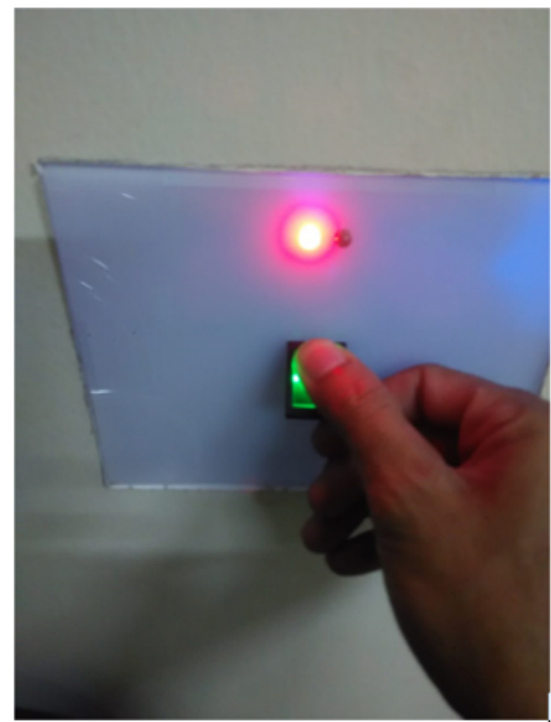

Gambar 9. Kegagalan Membuka Kunci pada Jari Tangan Kanan

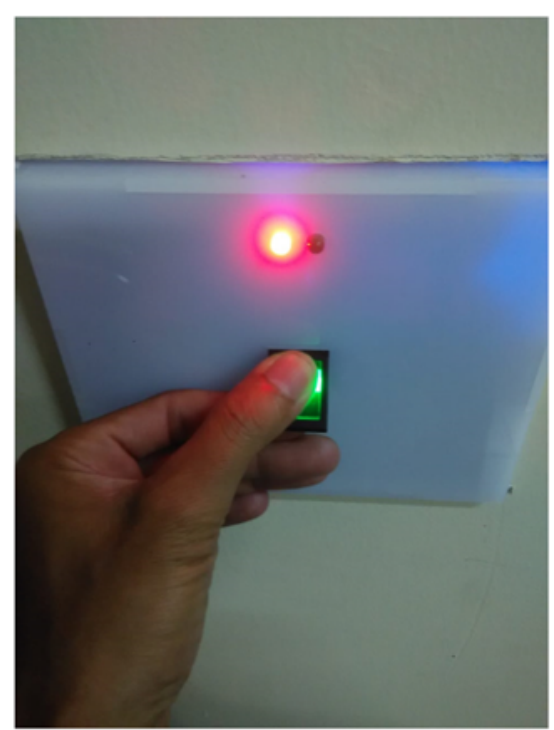

Gambar 10. Kegagalan Membuka Kunci pada Jari Tangan Kiri 
Tabel 3. Pengujian Sistem dengan Ibu Jari Tangan Kanan

\begin{tabular}{|c|c|c|}
\hline Percobaan $\boldsymbol{k e}$ - & Deteksi Jari & Kunci \\
\hline 1 & Terdeteksi & Terbuka \\
\hline 2 & Terdeteksi & Terbuka \\
\hline 3 & Terdeteksi & Terbuka \\
\hline 4 & Terdeteksi & Terbuka \\
\hline 5 & Terdeteksi & Terbuka \\
\hline 6 & Terdeteksi & Terbuka \\
\hline 7 & Terdeteksi & Terbuka \\
\hline 8 & Terdeteksi & Terbuka \\
\hline 9 & Terdeteksi & Terbuka \\
\hline 10 & Terdeteksi & Terbuka \\
\hline 11 & Terdeteksi & Terbuka \\
\hline 12 & Terdeteksi & Terbuka \\
\hline 13 & Terdeteksi & Terbuka \\
\hline 14 & Tidak Terdeteksi & Terkunci \\
\hline 15 & Terdeteksi & Terbuka \\
\hline 16 & Terdeteksi & Terbuka \\
\hline 17 & Terdeteksi & Terbuka \\
\hline 18 & Terdeteksi & Terbuka \\
\hline 19 & Terdeteksi & Terbuka \\
\hline 20 & Terdeteksi & Terbuka \\
\hline
\end{tabular}

Tabel 4. Pengujian Sistem dengan Ibu Jari Tangan Kiri

\begin{tabular}{|c|c|c|}
\hline Percobaan ke- & Deteksi Jari & Kunci \\
\hline 1 & Terdeteksi & Terbuka \\
\hline 2 & Terdeteksi & Terbuka \\
\hline 3 & Terdeteksi & Terbuka \\
\hline 4 & Terdeteksi & Terbuka \\
\hline 5 & Terdeteksi & Terbuka \\
\hline 6 & Tidak Terdeteksi & Terkunci \\
\hline 7 & Terdeteksi & Terbuka \\
\hline 8 & Terdeteksi & Terbuka \\
\hline 9 & Terdeteksi & Terbuka \\
\hline 10 & Terdeteksi & Terbuka \\
\hline 11 & Terdeteksi & Terbuka \\
\hline 12 & Terdeteksi & Terbuka \\
\hline 13 & Tidak Terdeteksi & Terkunci \\
\hline 14 & Terdeteksi & Terbuka \\
\hline 15 & Terdeteksi & Terbuka \\
\hline 16 & Terdeteksi & Terbuka \\
\hline 17 & Terdeteksi & Terbuka \\
\hline 18 & Terdeteksi & Terbuka \\
\hline 19 & Terdeteksi & Terbuka \\
\hline 20 & Terdeteksi & Terbuka \\
\hline & & \\
\hline
\end{tabular}

Berdasarkan pengujian yang dilakukan pada pembukaan kunci dengan tombol manual, tombol bisa bekerja dengan maksimal. Dari keseluruhan percobaan dapat diketahui bahwa sistem dapat berfungsi sesuai yang diharapkan. Performa sistem ketika beroperasi menggunakan input sidik jari tangan kanan memiliki tingkat keberhasilan sebesar 95\%, 90\% ketika menggunakan jari tangan kiri dan $100 \%$ ketika beroperasi menggunakan tombol manual. Sehingga secara keseluruhan sistem memiliki rata-rata keberhasilan 95\% dan tingkat kegagalan $5 \%$.

Tabel 5. Pengujian Kunci Pengaman dengan Tombol Manual

\begin{tabular}{|c|c|}
\hline Percobaan $\boldsymbol{k e}$ - & Kunci \\
\hline 1 & Terbuka \\
\hline 2 & Terbuka \\
\hline 3 & Terbuka \\
\hline 4 & Terbuka \\
\hline 5 & Terbuka \\
\hline 6 & Terbuka \\
\hline 7 & Terbuka \\
\hline 8 & Terbuka \\
\hline 9 & Terbuka \\
\hline 10 & Terbuka \\
\hline 11 & Terbuka \\
\hline 12 & Terbuka \\
\hline 13 & Terbuka \\
\hline 14 & Terbuka \\
\hline 15 & Terbuka \\
\hline 16 & Terbuka \\
\hline 17 & Terbuka \\
\hline 18 & Terbuka \\
\hline 19 & Terbuka \\
\hline 20 & Terbuka \\
\hline
\end{tabular}

\section{PENUTUP}

\section{Kesimpulan}

Sistem keamanan pintu berbasis sensor Fingerprint telah berhasil dirancang dan diimplementasikan pada Lab. Instrumentasi, Departemen Teknik Elektro dan Informatika, Sekolah Vokasi, UGM. Sensor Fingerprint mampu mendeteksi sidik jari pengguna untuk mengakses pintu Laboratorium. Sistem pengunci dibangun menggunakan Magnetic Lock dengan dilengkapi sistem pengunci otomatis ketika pintu ditutup serta dilengkapi pembuka kunci manual dari sisi dalam Laboratorium. Sistem secara keseluruhan memiliki rata-rata keberhasilan 95\% dan tingkat kegagalan $5 \%$ dalam pembacaan sidik jari. Sedangkan pada sistem pembukaan kunci manual memiliki keberhasilan 100\%.

\section{Saran}

Pengembangan sistem dengan mengintegrasi dengan jaringan listrik untuk mengatur fungsi 
fasilitas di dalam ruangan untuk mewujudkan konsep smartroom di lingkungan pendidikan.

\section{Ucapan Terima Kasih}

Para penulis mengucapkan terima kasih atas dukungan pendanaan Skema Penelitian Kompetitif yang diberikan oleh Departemen Teknik Elektro dan Informatika, Sekolah Vokasi, Universitas Gadjah Mada, Yogyakarta, Indonesia.

\section{DAFTAR PUSTAKA}

Arduino Nano User Manual, 2008, Retrieved from https://www.arduino.cc/en/uploads/Main/ ArduinoNanoManual23.pdf

Atzori, L., Iera, A., Morabito, G., 2010, "The Internet of Things: A survey", Computer Networks, Vol. 54(15), pp. 2787-2805.

Bregman, D., 2010, "Smart Home Intelligence The eHome that Learns", International Journal of Smart Home, Vol. 4. pp 35-46

Faraby, M. D., Ishak, Rukiah, Setiawan, 2016, Jurnal Teknologi Terapan, Politeknik Negeri Indramayu, Vol. 2, No. 2

Hanifah, A., Setiawan, I., Darjat, 2010, Aplikasi Smart Card Sebagai Pengunci Elektronis Pada Smart Home, Universitas Diponegoro. Semarang

Hugh, W., 2011, Using Fingerprint Authentication to Reduce System Security, Internasional Journal of Advancement in Research and Technology, ISSSN 2375-1207.

Iskandar, A., Muhajirin, Lisah, 2017, Sistem Keamanan Pintu Berbasis Arduino Mega. Jurnal Informatika Upgris, Jurusan Teknik Informatika, STMK AKBA. Vol.3, No. 2.

Kusriyanto, M. and B. D. Putra, 2016, "Smart home using local area network (LAN) based arduino mega 2560," 2016 2nd International Conference on Wireless and Telematics (ICWT), Yogyakarta, pp. 127131.

Saiful, M. A., 2016, Sistem Pengaman Pintu Rumah Menggunakan Fingerprint Scanner Berbasis Mikrokontroler, Tugas Akhir, Fakultas Teknologi Industri, Institut Teknologi Seputuh Nopember.

Saputra, D., Masud, A., H. Ramadhan, M. Fitriani, D., 2014, Akses Kontrol Ruangan Menggunakan Sensor Sidik Jari Berbasis Mikrokontroler ATMEGA328P. Jurnal,
Jurusan Teknik Informatika, STMIK Raharja, Tangerang, Banten.

Sinaga, T. dan Tamba, T., 2013, Sistem Presensi dengan Metode Sidik Jari Menggunakan Sensor Fingerprint dengan Tampilan PC, Jurnal Saintia Fisika, Universitas Sumatera Utara. Volume. 1 Nomor. 1.

Triawati, E. dan Firman A, 2010. Perancangan Smart Home Berbasis Programmable Logic Controller. Universitas Gunadarma, Depok 